\title{
Out of the Box
}

It's cognitive dissonance time, esteemed colleagues! Will we continue to boost omega-3 fatty acids while world fish stocks collapse? Will we continue to commend foods and drinks that travel thousands of miles and contribute to climate change? Do we still advocate low-fat diets to prevent heart disease, although the evidence is a house of cards?

\section{Are fish dished?}

Last year I mentioned a lead news story of The Daily Telegraph headlined: 'All seafood will run out in 2050, say scientists' ${ }^{\text {(1) }}$. Here is more. What Boris Worm of Dalhousie University in Nova Scotia and his colleagues actually say is that if commercial fishing practices remain unchanged, projections show elimination of wild fishing stock before mid-century ${ }^{(2)}$. A sea-change had better come pretty damn quick.

On the other side of Canada, marine biologists in Vancouver have estimated that global government and other subsidies from tax-payers' money for ocean floor trawling, also known as bottom dragging, which exterminates the breeding grounds of fish, amount to about \$US 150 million a year, whereas profits - assuming these average $10 \%$ of the value of the catch - are around \$US 100 million a year ${ }^{(3)}$. The business that is most efficient at making fish extinct is really running at a loss. Well hey, that's progress, also known as free trade and the open market, for you!

Total global subsidies of commercial fishing, excluding those for fuel, are estimated at about \$US 26 billion a year. Most is paid by countries with extensive coastlines India, Japan, European Union countries (mostly France, Spain and Portugal), Brazil, Russia, the USA and China, in that order ${ }^{(3)}$. Some have formed a club with a warm fuzzy name, The Friends of Fishers, whose policy is to maintain the subsidies, most of which go to highly capitalised fishing businesses and so also jeopardise the livelihoods of fishing communities. A report on fishing subsidies in Brazil concludes: 'If the economic logic does not consider the ecological logic of renewable natural resources, the result will be the extinction of the natural capital, resulting in terrible consequences for the nutritional requirement of generations of Brazilians to come ${ }^{\text {,(4). }}$.

The only effective solution is severe limits on big trawlers in international waters, using laws enforced by ocean police that will result in bankruptcy, dismissal and the slammer for offending owners and officers. A moratorium on bottom dragging proposed at the UN
Assembly at the end of 2006 was opposed by Japan, Russia, Canada and Iceland. Doha Round WTO discussions on reduction or elimination of subsidies for industrial trawling are still in session ${ }^{(5)}$. Don't hold your breath.

\section{How do we stay on the ball?}

So what about the omega-3 fatty acids found in fish, vital for mental function? Rates of diseases of the nervous system that don't yet get on official diet-related lists, such as multiple sclerosis, brain cancer and bipolar depression, continue to increase. Let's think about this, before it's too late.

Fish farming isn't a solution: apart from its ecological devastation, farmed fish are fed on - fish. The size of the world's population is the basic problem. A population of say 1 billion, as in the days just before industrialisation when Thomas Malthus prematurely predicted that population increase would overwhelm food supplies, might do the trick. But that suggests solutions outside the remit of public health nutritionists, such as more famines and genocides ${ }^{(6)}$, or else collision with an asteroid or World War III, both of which might result in a world human population of zero.

Perhaps we should all shut up about omega-3s, become private health nutritionists, write off the 5 billion helots soon to become 8 billion, and prescribe tabs of algae and flaxseed for well-heeled clients. Abolition of chemical-dependent rice farming and the re-introduction of carp into paddy would keep the grey matter of the southern Chinese and other Asians in good shape, but would be no help to wheat and potato eaters - not that this would concern the Chinese, already poised to take over the world.

At least we can all support our local traders. Here in Cabo Frio on the Rio de Janeiro state littoral I am doing my bit. We have been feasting on dourado, caught by the fishers who have been here for thousands of years since the time of the original Tamoios people, sold in the town's fish market, and simmered at home Bahia style with tomatoes, peppers, onions, garlic, coconut milk, parsley and urucúm.

\section{How big is your footprint?}

On the topic of 'think global, eat local', when I was in Vancouver recently my host Ryna Levy-Milne gave me a copy of The 100-Mile Diet ${ }^{(7)}$. This is a meditation on the wisely-led 
life and a celebration of wilderness. Its story is what happened to a British Columbian couple after they decided to spend a year consuming food and drink all of which came from within 100 miles of their homes in Vancouver and up-country by the Skeena River. Why? 'We could continue to decipher every far-flung product that appeared in our supermarket shelves. Or we could start fresh. We could immerse ourselves in the here and now, and the simple pleasures of eating would become a form of knowing'.

William Rees of the University of British Columbia, who co-originated the concept of the "ecological footprint ${ }^{\text {(8), }}$, helped to inspire the book. He remembered an occasion when, as a boy in the early 1950s, he and his large family gathered for lunch at his grandmother's country house. 'The baby carrots, the new potatoes, the fresh lettuce there wasn't a single footstuff on the plate that he hadn't had a hand in growing... He was so excited he couldn't eat his lunch. It was, like, everything was connected.

Richard Hebda of the Royal British Columbia Museum reckons that the west coast of Canada was once more densely populated than anywhere in the Americas, apart from the valley of Mexico. There are native legends of Dimlahamid, a great city on the Skeena. In exploring the abundance of their province, the authors of The 100-Mile Diet invite us to consider what being rich and being poor really mean now, and also in the near future as nonrenewable sources of fuel and water become scarce, expensive and rationed.

\section{End of a time of error?}

John Maynard Keynes celebrated middle-class life of a century ago, writing ${ }^{(9)}$ : 'The inhabitant of London could order by telephone, sipping his morning tea in bed, the various products of the whole earth... and reasonably expect their early delivery on his doorstep' and 'could adventure his wealth in the natural resources and new enterprises of any quarter of the world, and share, without exertion or even trouble, in their prospective fruits and advantages... [and]... regarded this state of affairs as normal, certain, and permanent'.

Those were innocent Edwardian days. Now it's reckoned that over $30 \%$ of greenhouse gases generated in EU countries come from food systems, more than half of which is from industrial meat production, but also nearly half is from food transport ${ }^{(10)}$. This isn't all about air travel. The International Maritime Organization estimates that globally aircraft emit something like 650 million tonnes of carbon dioxide every year, whereas the 90000 ships in the world's oceans (which true, carry far more goods) emit around 1.2 billion tonnes ${ }^{(11)}$.

For the most privileged people the extraordinary brief period of history celebrated by Maynard Keynes is not yet quite ended. My teatime cuppa Lapsang, purchased at Waitrose in London as one item of what I glumly tot up to my current 25000-mile diet, notwithstanding dourado, is beginning to feel like a prodigal affectation. There again, nobody's perfect. Maybe the denizens of Dimlahamid threw the local salmon, venison and bear steaks to their dogs, and dined off eagles, sturgeon and mammoths from the coasts of Cathay and the steppes of Siberia. There again, maybe that's why the city disappeared.

The Girksan people who still live in the Skeena region say: 'Great disasters are the landmarks of a people who are wise. They mark the ending of a time of error. They set a starting point for a better mode of life'. Here's hoping.

\section{A big fat point?}

As promised last month, here is what I think about Good Calories, Bad Calories ${ }^{(12)}$. It is a massive elaboration of a 2002 New York Times Magazine cover feature 'What if it's all been a big fat lie? ${ }^{\text {(13) }}$. The background is as follows. Gary Taubes, a New York City-based science writer, tried the high-fat, low-carbohydrate Atkins diet ${ }^{(14)}$, found that it worked for him, wondered why, and decided to find out.

The deeper he dug, the more convinced he became that (a) it's not dietary fat that causes obesity so much as sugar and other processed carbohydrates, which is sort-of what Robert Atkins claimed as from the early 1970s; and (b) the dietary fat hypothesis is said to be proved, but on examination the evidence is unimpressive. By contrast he says, with a lot of documentation, that (c) the sugar etc. hypothesis is at least as plausible and has been neglected - bluntly, suppressed.

He then found (d) that the fat makes you fat hypothesis, conventional wisdom as from the late 1970s and early 1980s, was agreed by a network of influential scientists who wanted the obesity story to square with the heart disease story originally fixed by the US establishment in $1961^{(15)}$, so as not to muddle the media and the public; and he became convinced that (e) the fat causes heart disease hypothesis has always been based on shaky science.

The sting in Gary Taubes's New York Times story was its title, and also the interviews he conducted with heavy-hitting scientists who as quoted supported his views - but who after publication furiously repudiated him $^{(16,17)}$. My information is that he did not misquote them. This may account for the limp title of his book. I hear that the publisher wanted the oomph of something like The Big Fat Lie, whereas he preferred a fence-mending title like Diet, Obesity and Coronary Heart Disease: An Alternative Hypothesis. As it is the title is oblique. This is a pity. Although the second half of the book is undigested, and his views on physical activity are silly, he does have a big fat point.

\section{So what causes heart disease?}

Reading Gary Taubes reminds me of a disturbing experience. In March 1984 I was flown to Tampa as one of a big group of specialist writers and media influencers, to attend the 24th annual conference of the American 
Heart Association on CVD epidemiology and to be told key results of the massive Multiple Risk Factor Intervention Trial (MRFIT), set up 14 years previously to follow 12866 men aged 35-59, selected from an original pool of 315662 , so as to find out how to prevent heart disease or to be exact, fatal heart attacks.

Jeremiah Stamler and the other principal investigators told everybody assembled in Tampa that the MRFIT results prove that lowering blood cholesterol by reducing dietary saturated fat and dietary cholesterol reduces the rate of death from heart disease. But the results were remarkable for being close to zip - nil. What the figures showed and what the scientists responsible for the study said the figures showed were different - or so it seemed to me.

Besides, how could a multiple risk intervention, including drugs to lower blood cholesterol and blood pressure, and supervised encouragement to start exercising and stop smoking, do more than suggest the relevance of diet? As Jerry Stamler wrote a few years before, a positive result could 'make only a limited, albeit valuable, contribution to the further elucidation of the matter of disease etiology', and a negative result, in what was a high-risk group of middle-aged men, could merely indicate 'too little and too late,(18).

The Tampa occasion was mighty impressive. Meetings in Britain on prevention of heart disease in those days might have filled a room at the Royal Society of Medicine and be discursive and inconclusive. This was nothing like that. At a media briefing Jerry Stamler stated the cost of MRFIT, which eventually amounted to \$US 115 million, paused, looked around and declaimed 'Peanuts!'; going on to say that in the war against heart disease, no expense should be spared. Comparisons were made with the cost and value of the space race. At the meeting itself, attended by over a thousand colleagues, he walked down the aisle of the packed amphitheatre-style auditorium towards his front seat to a thunderous ovation. It felt like a presidential convention. Talking to me about heart disease he said that MRFIT and such-like work had 'turned the flank of this huge problem'. But had it?

\section{Beef: what's the beef?}

By the 1980 s the original 1960 s canon $^{(15)}$ had already gone through a succession of modifications. The dietary cholesterol story never really caught on in Europe. Total fat survived because it was positioned as a cause of obesity, which increases the risk of heart disease. But the case against total saturated fats was not questioned. For people in high-income countries, this is interpreted as less milk, less butter and cheese, and less meat - or else low-fat and lean versions - as well as less fatty processed foods.

By the mid-1980s specialists in the field generally agreed that total saturated fats and cholesterol are important dietary causes of heart disease, together with total fats as a cause of obesity and thus heart disease. Internationally this position was reinforced by a WHO report whose expert panel was chaired by Geoffrey Rose of the London School of Hygiene and Tropical Medicine ${ }^{(19)}$.

Then from the mid-1980s the story changed again, with trans fats, notably as found in highly processed fatty foods such as hard margarines, biscuits and other baked goods, positioned as the new villain, as bad as if not worse than saturated fats. All this is now reflected in the health claims and nutrition labels of tens of thousands of processed products, as you can see.

The successive shifts in conventional wisdom have also provoked a vast proliferation of processed foods, with mouth-feel and yumminess bumped up with more processed sugars and starches, cosmetic additives, and no doubt other chemicals whose purpose is to get you into the habit of consuming the product. Some of these carry seals of approval from august bodies such as the American Heart Association, for which substantial fees are charged $^{(20)}$. And as Gary Taubes says: 'The 70 s come around. We decide that fat gives you heart disease. We have to eat low-fat diets, low-fat diets heavy in starches and sugars, and we start getting fatter, ${ }^{\text {(21) }}$.

Successive expert reports continue to try to hold a consistent line on fats and heart disease. But the story has become increasingly muddled. Is it total fat, total saturated fats, and cholesterol? Or total fat, total saturated fats, lack of total polyunsaturated fats, and cholesterol? Or total saturated fats plus total fats as a cause of overweight and obesity and thus heart disease? Or total saturated fats and trans fats? Or what? And where do the types of fat that are known to protect against various diseases fit into these pictures? When you translate the chemistry back into foods and drinks, it makes a difference. Are eggs and shrimps out or in? What about butter? What about beef?

Two recent reports modify the original story even further. In its text on heart disease the 2003 WHO report on prevention of chronic diseases ${ }^{(22)}$ toes the line on saturated fats in the text, and emphasises that there are good fats as well as bad fats. But in the matrices displaying the panel's judgements, while the evidence against the saturated myristic and palmitic fatty acids is judged to be convincing, along with trans fatty acids, stearic fatty acid as contained in beef and other red meat (with other saturated fats) is judged to have probably no relationship with heart disease. Total fat, and any fatty acid fractions, do not figure in the matrices displaying panel judgements on weight increase and obesity, either in the WHO report or in the $2007 \mathrm{WCRF} / \mathrm{AICR}$ report ${ }^{(23)}$ chapter on determinants of obesity. Instead, energy-dense foods are featured. Yes, these include fatty foods - and also sugared foods.

It's time for a paradigm shift. My view is different from that of Gary Taubes. The one hypothesis that fits the facts is that the issue, with obesity, heart disease and other diseases, is not food seen in terms of its chemical composition. Confusing food with its chemistry (which is 
to say, currently known chemical constituents), an approach that has dominated nutrition science since the early 19th century, which originally made sense, is now in the circumstances of the 21st century an error. The main issue is malign food and drink production and processing. Our task now includes identifying and promoting benign agriculture and manufacture technologies, in careful collaboration with industry.

Once I had tea with Jerry Stamler in London. The waitress arrived with a tray including wrapped pats of Anchor butter, for our scones. 'Haven't you people beard?', Jerry declaimed, and ordered margarine. Packets of Flora, which in those days included trans fats, duly arrived. We would have been better off with the butter, which also tastes good.

\section{Acknowledgements}

Sources of funding: My work for World Cancer Research Fund International enables me to travel. My flight to and from Vancouver and accommodation were paid by the British Columbia Cancer Agency; my thanks to Simon Sutcliffe and Ryna Levy-Milne. My 1984 trip to Tampa was funded by Unilever, and specifically by the public relations company representing Flora.

Competing interests: Flora is the high polyunsaturated margarine now positioned as a functional food, claimed to be positively protective against heart disease. At the time this allowed me to quip that Florida had become Flora with an added 'id'. Yes, as a self-employed writer I knew that The Times would not pay for my trip. Yes, I did feel pressure to toe the line, tried to resolve the problem by avoiding reference to polyunsaturates in the articles I wrote, and did not get offered another trip. With Claus Leitzmann I am co-convenor of the International Union of Nutritional Sciences/World Health Policy Forum New Nutrition Science project, whose spiral motif accompanies this column.

Authorship responsibilities: Colin Tudge pointed me to Richard Moore's incredible take on the hidden agenda of the Al Gore-influenced post Bush II administration ${ }^{(6)}$. Other people who contributed to the ideas in this column are acknowledged in the text and references below. Other sources are I hope properly referenced. Sweeping statements, flights of fancy and Internet rummaging, by

Geoffrey Cannon GeoffreyCannon@aol.com

\section{References}

1. Clover C (2006) All seafood will run out in 2050, say scientists. The Daily Telegraph, 3 November.
2. Meek J (2006) 'Faith-based science' and all that fish. Chronicle Herald, Halifax, 6 December; available from meek@ns.sympatico.ca

3. Sumaila UR \& Pauly D (eds) (2006) Catching More Bait. A Bottom-Up Re-estimation of Global Fisheries Subsidies (2nd version, 2007). Fisheries Centre Research Reports 14(6); http://www.fisheries.ubc.ca/publications/reports/14-6.pdf

4. Abdallah PR \& Sumaila UR (2006) A historical account of Brazilian policy on fisheries subsidies. In Catching More Bait. A Bottom-Up Re-estimation of Global Fisheries Subsidies (2nd version, 2007). Fisheries Centre Research Reports 14(6), 68-77; http://www.fisheries.ubc.ca/publications/reports/14-6.pdf

5. Stier K (2007) Laying waste to the deep sea. Time, 13 December.

6. Moore R (2006) Escaping the Matrix: How We the People Can Change the World. Redwood City, CA: The Cyberjournal Project; see also www.richard@cyberjournal.org

7. Smith A \& MacKinnon J (2007) The 100-Mile Diet. A Year of Local Eating. Toronto: Vintage [in USA: Plenty. One Man, One Woman, and a Robust Year of Eating Locally. New York: Crown. 2007]; see also www.100milediet.org

8. Wackernagel M \& Rees W (1996) Our Ecological Footprint. Reducing Human Impact on the Earth. Gabriola Island BC, Canada: New Society Press; see also www.globalfootprint.org

9. Keynes J (1919) Introduction. In The Economic Consequences of the Peace. London: Macmillan.

10. Oliver R (2007) All about food and the environment. CNN News, 21 November; www.cnn/2007/BUSINESS/11/21/eco.food. Accessed 30 December 2007.

11. Howden D (2007) Shipping pollution 'far more damaging than flying'. The Independent, 10 October.

12. Taubes G (2007) Good Calories, Bad Calories. Challenging the Conventional Wisdom on Diet, Weight Control, and Disease. New York: Knopf [in UK: The Diet Delusion. London: Vermilion, 2008].

13. Taubes G (2002) What if it's all been a big fat lie? The New York Times Magazine, 7 July.

14. Atkins R (1999) Dr Atkins' New Diet Revolution, revised ed. New York: Avon.

15. American Heart Association (1961) Dietary fat and its relation to heart attacks and strokes. Report by the Central Committee for Medical and Community Program of the American Heart Association. J Am Med Assoc 175, 389-391.

16. Liebman B (2002) The truth about the Atkins diet. Nutrition Action Healthletter 29(9); http://www.cspinet.org/nah/ 11_02/bigfatlies.pdf

17. Fumento M (2003) Big fat fake. Reason Online, March; http://www.reason.com/news/show/28714.html

18. Stamler J (1979) Population studies. In Nutrition, Lipids, and Coronary Heart Disease [R Levy, B Rifkind, B Dennis and R Ernst editors]. New York: Raven Press.

19. World Health Organization (1982) Prevention of Coronary Heart Disease. Report of a WHO Expert Committee. Technical Report Series no. 678. Geneva: WHO.

20. Nestle M (2006) Packaged foods: health endorsements. In What To Eat, Chapter 29. New York: Farrar Straus Giroux.

21. FRONTLINE (2004) Interview with Gary Taubes; http:// www.pbs.org/wgbh/pages/frontline/shows/diet/interviews/ taubes.html

22. World Health Organization (2003) Diet, Nutrition and the Prevention of Chronic Diseases. Report of a Joint WHO/FAO Expert Consultation. Technical Report Series no. 916. Geneva: WHO.

23. World Cancer Research Fund/American Institute for Cancer Research (2007) Food, Nutrition, Physical Activity, and the Prevention of Cancer: A Global Perspective. Washington DC: AICR. 